\title{
Dobór urządzeń do zgrzewania oporowego punktowego z wykorzystaniem analizy skupień
}

\author{
Selection of resistance spot-welding machines \\ with the use of cluster analysis
}

\section{Streszczenie}

W pracy omówiono zagadnienie doboru urządzeń do zgrzewania oporowego punktowego, stwierdzając na podstawie przeglądu literatury, że nie istnieje obiektywna metoda wspomagająca decyzję zakupu takich zgrzewarek. Do rozwiązania problemu zaproponowano zastosowanie metod analizy skupień. Zgromadzono i opracowano dane diagnostyczne opisujące 35 zgrzewarek oporowych punktowych, a następnie przeprowadzono ich klasyfikacje metodami Warda i k-średnich. Na podstawie porównania wyników wykazano, że analiza skupień może być stosowana jako wstępna metoda wspomagania decyzji zakupu urządzeń do zgrzewania oporowego punktowego.

Słowa kluczowe: zgrzewanie oporowe punktowe; analiza skupień; metoda Warda; metoda k-średnich; zakup

\begin{abstract}
The paper presents the issue of selection of the resistance spot-welding machines, stating that there is no objective method of supporting the decision to purchase such devices. The application of cluster analysis method has been suggested for solving the problem. Diagnostic data describing 35 resistance spot-welding machines have been collected and then their classification has been made by the Ward and k-means methods. Based on the results, it has been concluded, that the cluster analysis can be an effective preliminary method of supporting the decision of purchasing resistance spot-welding machines.
\end{abstract}

Keywords: resistance spot welding; cluster analysis; Ward's method; k-means method; purchasing

\section{Wstęp}

Zgrzewanie jest jedną z podstawowych technik wytwarzania [1]. Na skalę przemysłową stosuje się wiele procesów zgrzewania, których idea bazuje najczęściej na zamianie energii elektrycznej albo mechanicznej na cieplną wykorzystywaną do nagrzania spajanych elementów. Do najbardziej rozpowszechnionych metod można zaliczyć: zgrzewanie oporowe doczołowe i punktowe [2 $\div 4]$, tarciowe [5,6], w tym FSW [7] oraz wybuchowe [8,9] i łukiem wirującym [10].

Rozwój zgrzewania oporowego związany był z potrzebami rynku oraz postępem w i elektrotechnice i elektronice. Proces ten na masową skalę został zaaplikowany m.in. w artykułach gospodarstwa domowego oraz przemyśle motoryzacyjnym (np. do łączenia elementów nadwozi pojazdów).

W większości przypadków, aby można było uzyskać złącza zgrzewane spełniające założone kryteria akceptacji wynikające między innymi z norm przedmiotowych oraz specyfikacji technicznych, należy stosować specjalistyczne i odpowiednio wyposażone stanowiska robocze. Ich głównym i zasadniczym elementem jest zgrzewarka. Zgrzewarki oporowe punktowe można podzielić wg typu konstrukcji na stacjonarne, stołowe i kleszczowe. Urządzenia te do zasilania elektrod mogą wykorzystywać prąd przemienny, prąd stały albo energię akumulowaną. Osobna klasyfikacja (wg kryterium rodzaju wykonywanych złączy) dzieli je na zgrzewarki punktowe, garbowe i liniowe [11]. Większość spośród obecnie produkowanych urządzeń do zgrzewania stanowi złożone i wyposażone w zaawansowane funkcje rozwiązania konstrukcyjne, co utrudnia wybór modelu dopasowanego do aktualnych, często ściśle zdefiniowanych, potrzeb użytkownika. Podczas wyboru modelu urządzenia można kierować się m.in. doświadczeniem, wymaganiami specyfikacji technicznych czy norm przedmiotowych, rozwiązaniami konstrukcyjnymi zgrzewanych urządzeń, zapewnieniami producentów oraz własnymi odczuciami i opiniami innych użyt-

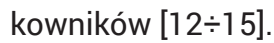

Do rozwiązywania złożonych problemów o charakterze wielowymiarowym przeznaczone są techniki Data Mining pozwalające na wyszukiwanie zależności wśród dużej ilości danych [16]. Jedną z nich jest analiza skupień stanowiąca odrębną gałąź wielowymiarowej analizy statystycznej,

Mgr inż. Monika Kędziorska - Koło Naukowe Spawalników MMA, dr inż. Aleksandra Świerczyńska, dr inż. Grzegorz Rogalski, dr hab. inż. Dariusz Fydrych - Politechnika Gdańska.

Autor korespondencyjny/Corresponding author: darfydry@pg.edu.pl 
której ideą jest grupowanie obiektów w możliwie jednorodne skupienia. Algorytm grupowania polega na podziale obiektów na skupienia, przy czym nadrzędnym celem jest zminimalizowanie zmienności wewnątrz skupień i zmaksymalizowanie zmienności między nimi. Metody analizy skupień znalazły zastosowanie w wielu dziedzinach nauk humanistycznych, ści-

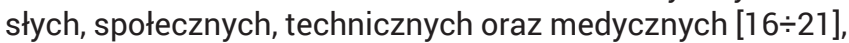
jednak rozwiązania problemów spajania z ich użyciem ograniczają się do jednostkowych przypadków. W szczególności w obszarze obejmującym procesy spawalnicze analiza skupień była stosowana do klasyfikacji urządzeń do spawania metodami MAG, TIG, elektrodą otuloną oraz oceny jakości zgrzewania oporowego punktowego [12,13,22,23].

Z wyżej wymienionych przyczyn podjęcie próby opracowania metody wspomagania decyzji zakupu o bardziej obiektywnym charakterze ujmującej jako kryteria czynniki ilościowe należy uznać za celowe. $Z$ analizy literatury dotyczącej możliwości doboru i zakupu urządzeń spawalniczych wynika, że brakuje opracowań porównujących parametry techniczne oraz ekonomiczne poszczególnych grup źródeł prądu do zgrzewania elektrycznego oporowego [12,13].

\section{Badania własne}

Głównym celem pracy było zweryfikowanie skuteczności technik analizy skupień jako metod wspomagania decyzji zakupu stacjonarnych zgrzewarek oporowych punktowych. Do pozostałych celów należało: wyselekcjonowanie cech diagnostycznych o żądanych własnościach dyskryminacyjnych oraz minimalizację ich ilości. Ograniczenie liczności cech miało na celu ułatwienie realizacji analiz oraz objaśnienia otrzymanych wyników.

Zakres pracy obejmował następujące etapy:

- zgromadzenie i opracowanie danych wejściowych do ana-

liz statystycznych:

- analiza zmienności danych dla kryterium maksymalnej wartości współczynnika zmienności: $\omega=0,2$;

- analiza korelacji cech diagnostycznych;

- normalizacja danych;

- przeprowadzenie analiz statystycznych:

- analiza skupień na podstawie cech diagnostycznych urządzeń metodą aglomeracyjną (Warda);

- analiza skupień na podstawie cech diagnostycznych urządzeń metodą k-średnich;

- zestawienie uzyskanych wyników oraz sformułowanie wniosków.

Dane wejściowe zostały zebrane na postawie ofert handlowych producentów i dystrybutorów stacjonarnych zgrzewarek oporowych punktowych. Zgromadzono dane techniczno-ekonomiczne charakteryzujące 35 modeli urządzeń oferowanych przez 4 producentów (tabl. I). W przypadku podania przez producenta zakresu danych przyjmowano wartość średnią. Wszystkim urządzeniom przyporządkowano nowe, zakodowane oznaczenia w postaci litery $C$ oraz liczby z zakresu $1 \div 35$. Następnie przeprowadzono analizę zmienności danych zgodnie z zależnością [16]:

$$
\omega=\frac{s_{j}}{X_{j}}
$$

gdzie:

$\omega$ - współczynnik zmienności;

$s_{j}$ - odchylenie standardowe;

$x_{j}$ - średnia arytmetyczna wartości cechy.

W tablicy I przedstawiono wszystkie analizowane cechy diagnostyczne wraz z wartościami współczynnika zmienności. Ponieważ we wszystkich przypadkach wartość ta nie była niższa niż 0,2 przyjęto, że wytypowane cechy charakteryzują się odpowiednią zdolnością dyskryminacyjną.
Tablica I. Cechy diagnostyczne oraz wartości współczynnika zmienności

Table I. Diagnostic factors and values of the coefficient of variation

\begin{tabular}{|c|c|c|}
\hline Cecha diagnostyczna & $\begin{array}{c}\text { Symbol cechy } \\
\text { diagnostycznej }\end{array}$ & $\begin{array}{c}\text { Współczynnik } \\
\text { zmienności } \omega\end{array}$ \\
\hline Moc nominalna P50\% & $\mathrm{P}_{\text {nom }}[\mathrm{kVA}]$ & 0,94 \\
\hline Maksymalna moc zgrzewania & $\mathrm{P}_{\max }[\mathrm{kVA}]$ & 1,31 \\
\hline Prąd zwarcia & $\mathrm{I}_{\text {zwarcia }}[\mathrm{kA}]$ & 0,63 \\
\hline $\begin{array}{c}\text { Maksymalny prąd } \\
\text { zgrzewania stali }\end{array}$ & $\mathrm{I}_{\max }[\mathrm{kA}]$ & 0,62 \\
\hline Chłodzenie wodne & $\mathrm{CH}[\mathrm{l} / \mathrm{min}]$ & 0,79 \\
\hline Masa netto & $\mathrm{M}[\mathrm{kg}]$ & 0,89 \\
\hline Rozstaw elektrod & $\mathrm{R}[\mathrm{mm}]$ & 0,32 \\
\hline Wysięg ramion & $\mathrm{W}[\mathrm{mm}]$ & 0,43 \\
\hline Maksymalny docisk elektrod & $\mathrm{D}_{\max }[\mathrm{daN}]$ & 0,57 \\
\hline Cena & $\mathrm{C}[\mathrm{PLN}]$ & 0,52 \\
\hline Okres gwarancji & $\mathrm{G}[\mathrm{mies}]$ & 0,52 \\
\hline
\end{tabular}

W oparciu o macierz korelacji cech stacjonarnych zgrzewarek oporowych punktowych wygenerowaną w programie Statistica oraz analizę merytoryczną procesu zgrzewania usunięto ze zbioru cech diagnostycznych maksymalną moc zgrzewania $P_{\max }$ oraz prąd zwarcia $I_{\text {zwarcia }}$ uznając, że cechą dobrze reprezentującą moc zgrzewarki jest maksymalny prąd zgrzewania stali $I_{\max }$. Do dalszych badań przyjęto zatem następujący zestaw cech diagnostycznych: moc nominalna Pnom, maksymalny prąd zgrzewania stali $I_{\max }$, chłodzenie wodne $\mathrm{CH}$, masa netto $\mathrm{M}$, rozstaw elektrod $\mathrm{R}$, wysięg ramion $W$, maksymalny docisk elektrod $D_{\max }$, cena $C$, okres gwarancji G. W tablicy II przedstawiono dane wejściowe do analiz w postaci surowej.

Normalizację cech przeprowadzono z uwzględnieniem ich podziału na stymulanty i destymulanty, przy czym do tych ostatnich zaliczono: masę oraz cenę. Zastosowano w tym celu zależności [16]:

dla stymulant:

$$
x_{i j}^{1}=\frac{x_{i j}-\min \left\{x_{i j}\right\}}{\max \left\{x_{i j}\right\}-\min \left\{x_{i j}\right\}}
$$

dla destymulant:

$$
x_{i j}^{1}=\frac{\max \left\{x_{i j}\right\}-x_{i j}}{\max \left\{x_{i j}\right\}-\min \left\{x_{i j}\right\}}
$$

gdzie:

$X_{\text {in }}$ - normalizowana wartość cechy;

$x_{i j}$ - wartość cechy.

Przygotowany w ten sposób zbiór danych został wykorzystany do przeprowadzenia analiz taksonomicznych w programie Statistica w dwóch etapach: metodą Warda z odległością euklidesową oraz metodą k-średnich dla opcji: sortuj odległości i weź obserwacje przy stałym interwale. Wybrano tym samym dwie metody analizy skupień, które stosowano z powodzeniem do rozwiązywania podobnych problemów technicznych [12,13]. Cechy w postaci znormalizowanej oznaczono dodatkowo indeksem N. Dendrogram przedstawiony na rysunku 1 został sporządzony z uwzględnieniem wszystkich cech diagnostycznych z tablicy II, 
Tablica II. Zbiór danych w postaci surowej

Table II. Raw input data for statistical analysis

\begin{tabular}{|c|c|c|c|c|c|c|c|c|c|}
\hline $\begin{array}{l}\text { Oznaczenie } \\
\text { urządzenia }\end{array}$ & $\begin{array}{c}\text { Moc } \\
\text { nominalna } \\
P_{\text {nom }} \\
\text { [kVA] }\end{array}$ & $\begin{array}{l}\text { Maksymal- } \\
\text { ny prąd } \\
\text { zgrzewania } \\
\text { stali I }{ }_{\max } \\
\text { [kA] }\end{array}$ & $\begin{array}{c}\text { Chłodzenie } \\
\text { wodne } \\
\mathrm{CH} \\
\text { [l/min] }\end{array}$ & $\begin{array}{c}\text { Masa } \\
\text { netto } \\
\text { M } \\
\text { [kg] }\end{array}$ & $\begin{array}{c}\text { Rozstaw } \\
\text { elektrod } \\
\mathbf{R} \\
{[\mathrm{mm}]}\end{array}$ & $\begin{array}{c}\text { Wysięg } \\
\text { ramion } \\
\text { W } \\
\text { [mm] }\end{array}$ & $\begin{array}{c}\text { Maksymalny } \\
\text { docisk } \\
\text { elektrod } \\
D_{\max } \\
\text { [daN] }\end{array}$ & $\begin{array}{l}\text { Cena } \\
\text { C } \\
\text { [PLN] }\end{array}$ & $\begin{array}{c}\text { Okres } \\
\text { gwarancji } \\
\text { G } \\
\text { [mies.] }\end{array}$ \\
\hline $\mathrm{C}-1$ & 30 & 15,2 & 6 & 193 & 417,5 & 440 & 425 & 14500 & 24 \\
\hline $\mathrm{C}-2$ & 30 & 15,2 & 6 & 185 & 436,5 & 400 & 470 & 14500 & 24 \\
\hline C-3 & 100 & 48 & 18 & 650 & 325 & 385 & 736 & 25000 & 24 \\
\hline$C-4$ & 100 & 44 & 17 & 710 & 325 & 800 & 736 & 25000 & 24 \\
\hline C-5 & 35 & 13,7 & 4 & 218 & 195 & 440 & 360 & 14760 & 24 \\
\hline C-6 & 35 & 11,1 & 4 & 223 & 195 & 640 & 618 & 10570 & 24 \\
\hline$C-7$ & 50 & 17,2 & 4 & 228 & 195 & 440 & 360 & 19360 & 24 \\
\hline $\mathrm{C}-8$ & 50 & 12,7 & 4 & 223 & 195 & 640 & 618 & 15760 & 24 \\
\hline C-9 & 90 & 25,6 & 11 & 550 & 325 & 803 & 736 & 23200 & 24 \\
\hline C-10 & 180 & 48 & 18 & 600 & 325 & 803 & 736 & 26850 & 24 \\
\hline C-11 & 16 & 10 & 2,5 & 135 & 220 & 390 & 376 & 10800 & 24 \\
\hline C-12 & 20 & 11,6 & 3 & 143 & 220 & 390 & 376 & 9500 & 24 \\
\hline C-13 & 20 & 9,6 & 3 & 146 & 220 & 540 & 520 & 9700 & 24 \\
\hline C-14 & 25 & 14,4 & 3,7 & 145 & 220 & 390 & 376 & 13580 & 24 \\
\hline C-15 & 25 & 11,6 & 3,7 & 148 & 220 & 540 & 520 & 10287 & 24 \\
\hline C-16 & 80 & 23,3 & 10 & 750 & 290 & 700 & 900 & 9799 & 12 \\
\hline C-17 & 120 & 24,8 & 10 & 820 & 290 & 700 & 900 & 12480 & 12 \\
\hline C-18 & 160 & 36 & 15 & 1550 & 365 & 1000 & 1500 & 17500 & 12 \\
\hline C-19 & 16 & 9,6 & 5 & 230 & 410 & 450 & 220 & 9040 & 12 \\
\hline C-20 & 25 & 12 & 5 & 240 & 410 & 450 & 220 & 12450 & 12 \\
\hline $\mathrm{C}-21$ & 40 & 17,2 & 5 & 260 & 410 & 450 & 300 & 9900 & 12 \\
\hline $\mathrm{C}-22$ & 8 & 7,3 & 2,5 & 225 & 160 & 215 & 220 & 10233 & 6 \\
\hline $\mathrm{C}-23$ & 12 & 9 & 2,5 & 200 & 160 & 215 & 220 & 9300 & 6 \\
\hline $\mathrm{C}-24$ & 8 & 7,3 & 2,5 & 112 & 160 & 215 & 360 & 10900 & 6 \\
\hline C-25 & 12 & 9 & 2,5 & 600 & 160 & 215 & 360 & 9775 & 6 \\
\hline C-26 & 20 & 12 & 3 & 170 & 250 & 315 & 360 & 14576 & 6 \\
\hline $\mathrm{C}-27$ & 30 & 16 & 6 & 380 & 250 & 315 & 360 & 15576 & 6 \\
\hline $\mathrm{C}-28$ & 50 & 20,5 & 10 & 225 & 250 & 315 & 360 & 9900 & 6 \\
\hline C-29 & 20 & 12 & 3 & 200 & 250 & 315 & 420 & 17000 & 6 \\
\hline C-30 & 30 & 16 & 6 & 255 & 250 & 315 & 420 & 17000 & 6 \\
\hline C-31 & 50 & 20,5 & 10 & 190 & 250 & 315 & 420 & 20947 & 6 \\
\hline C-32 & 13 & 9,7 & 0,95 & 104 & 195 & 330 & 150 & 8280 & 12 \\
\hline C-33 & 22 & 16,4 & 0,95 & 141 & 195 & 330 & 220 & 9360 & 12 \\
\hline $\mathrm{C}-34$ & 13 & 9,7 & 0,95 & 109 & 195 & 330 & 150 & 10800 & 12 \\
\hline C-35 & 22 & 16,4 & 0,95 & 145 & 195 & 330 & 220 & 12096 & 12 \\
\hline
\end{tabular}


tj.: $P_{\text {nom }} N, I_{\max } N, C H N, M N, R N, W N, D_{\max } N, C N, G N$ (analiza I). Dendrogram stanowi graficzną interpretację podziału elementów na skupienia, przy czym wyznaczenie ilości skupień można dokonać „odcinając" gałęzie drzewa na odpowiednim poziomie kierując się różnymi kryteriami [16]. W oparciu o wykres odległości wiązania względem wiązania (wykres przebiegu aglomeracji) pokazany na rysunku 2 wyznaczono liczbę skupień - 3, którą wprowadzono jako kryterium do analiz metodą k-średnich. Wyniki analizy metodą kśrednich pokazano na rysunku 3 , natomiast w tablicy III zestawiono wyniki obu analiz wraz z charakterystyką skupień. Z analizy zestawienia wynika, że zastosowanie dwóch różnych metod taksonomicznych poskutkowało utworzeniem niemal identycznych skupień. Jedynie 3 urządzenia (C-19, C-20 i C-21) zostały przypisane w każdej z analiz do innej grupy.

Drugą analizę przeprowadzono przyjmując założenie, że podczas podejmowania decyzji zakupu urządzenia spawalniczego można kierować się cechami diagnostycznymi

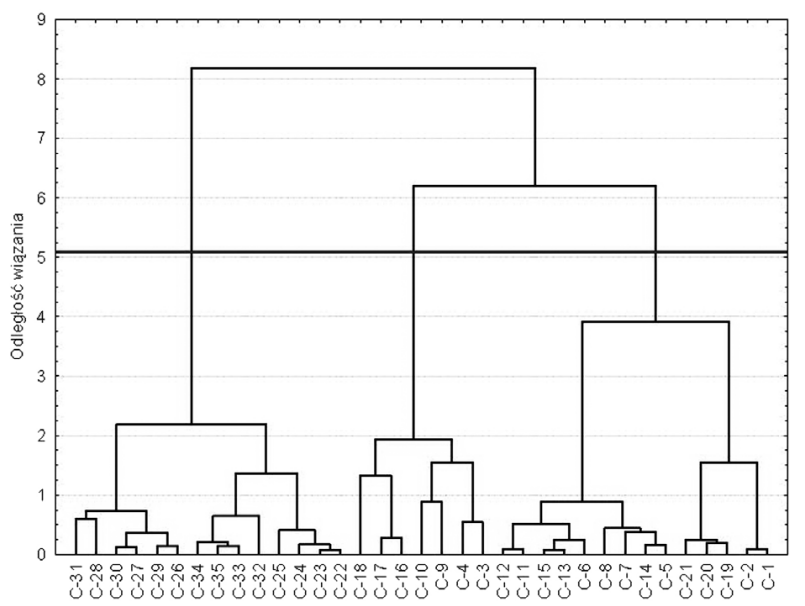

Rys. 1. Dendrogram klasyfikacji stacjonarnych zgrzewarek oporowych punktowych na podstawie cech: $P_{n o m} N, I_{\max } N, C H N, M N, R N$, WN, $D_{\max } N, C N, G N$. Metoda Warda, odległość euklidesowa. Przerywaną linią zaznaczono poziom podziału na skupienia (analiza I) Fig. 1. Euclidean distance dendrogram (Ward method) of stationary resistance spot-welding machines. Diagnostic factors: $\mathrm{P}_{\text {nom }} \mathrm{N}, I_{\max } \mathrm{N}$, CHN, MN, RN, WN, $D_{\max } N, C N, G N$. The dashed line indi-cates the best option to divide the dendro-gram into clusters (analysis I)

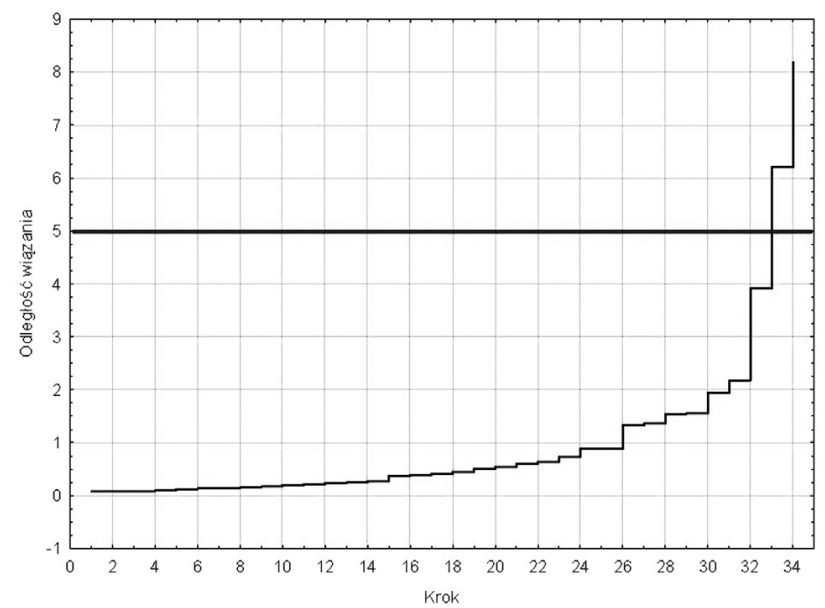

Rys. 2. Wykres odległości wiązania względem kroku wiązania (analiza I) Fig. 2. Graph of the distance of the binding relative to the binding step (analysis I)

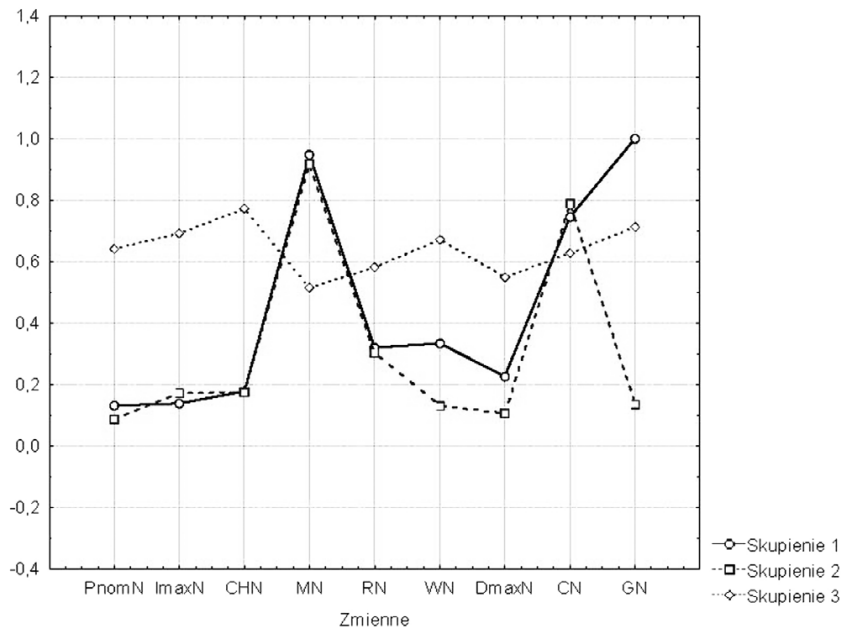

Rys. 3. Wykres liniowy średnich dla poszczególnych skupień stacjonarnych zgrzewarek oporowych punktowych na podstawie cech: $\mathrm{P}_{\text {nom }} \mathrm{N}, \mathrm{I}_{\max } \mathrm{N}, \mathrm{CHN}, \mathrm{MN}, \mathrm{RN}, \mathrm{WN}, \mathrm{D}_{\max } \mathrm{N}, \mathrm{CN}, \mathrm{GN}$ (analiza I)

Fig. 3. K-means plot for clusters of stationary resistance spotwelding machines. Diag-nostic factors: $P_{\text {nom }} N, I_{\max } N, C H N, M N, R N$, $\mathrm{WN}, \mathrm{D}_{\max } \mathrm{N}, \mathrm{CN}, \mathrm{GN}$ (analysis I)

Tablica III. Wyniki grupowania stacjonarnych zgrzewarek oporowych punktowych na podstawie cech: $P_{\operatorname{nom}} N, I_{\max } N, C H N, M N, R N, W N, D_{\max } N$, CN, GN (analiza I)

Table III. Results of the grouping of stationary resistance spot-welding machines on the basis of the following factors: $P_{\text {nom }} N, I_{\max } N, C H N$, $\mathrm{MN}, \mathrm{RN}, \mathrm{WN}, \mathrm{D}_{\max } \mathrm{N}, \mathrm{CN}, \mathrm{GN}$ (analysis I)

\begin{tabular}{|c|c|c|c|}
\hline $\begin{array}{c}\text { Numer } \\
\text { skupienia }\end{array}$ & Elementy skupienia (metoda Warda) & Elementy skupienia (metoda k-średnich) & Opis skupienia \\
\hline \multirow{1}{*}{1} & $\begin{array}{c}\text { C-22, C-23, C-24, C-25, C-26, C-27, C-28, } \\
\text { C-29, C-30, C-31, C-32, C-33, C-34, C-35 }\end{array}$ & $\begin{array}{c}\text { C-19, C-20, C-21, C-22, C-23, C-24, C-25, C-27, C-28, C-29, C-30, C-31, C-32, } \\
\text { C-33, C-34, C-35 }\end{array}$ & $\begin{array}{c}\text { Niskie parametry, niemal najcięższe } \\
\text { urządzenia, najmniejszy: rozstaw, } \\
\text { wysięg, docisk elektrod, najniższa cena, } \\
\text { najkrótszy okres gwarancji }\end{array}$ \\
\hline \multirow{2}{*}{2} & C-3, C-4, C-9, C-10, C-16, C-17, C-18 & C-3, C-4, C-9, C-10, C-16, C-17, C-18 & $\begin{array}{c}\text { Niskie parametry, najcięższe urządze- } \\
\text { największy rozstaw, średni wysięg } \\
\text { i docisk elektrod, najwyższa cena, } \\
\text { najdłuższy okres gwarancji }\end{array}$ \\
\hline \multirow{3}{*}{3} & $\begin{array}{c}\text { C-1, C-2, C-5, C-6, C-7, C-8, C-11, C-12, } \\
\text { C-13, C-14, C-15, C-19, C-20, C-21, }\end{array}$ & C-1, C-2, C-5, C-6, C-7, C-8, C-11, C-12, \\
& C-13, C-14, C-15 & $\begin{array}{c}\text { Wysokie parametry zgrzewania, najlżej- } \\
\text { sze urządzenia, największy: rozstaw, } \\
\text { wysięg, docisk elektrod, wysoka cena, } \\
\text { przeciętny okres gwarancji }\end{array}$ \\
\hline
\end{tabular}


odpowiadającymi podstawowemu parametrowi technologicznemu: mocy nominalnej $\mathrm{P}_{\text {nom }} \mathrm{N}$ i parametrowi ekonomicznemu: okresem gwarancji GN, a następnie z określonych w ten sposób zbiorów wybrać zgrzewarki o najniższej cenie. Na rysunkach $4 \div 6$ i w tablicy IV przedstawiono wyniki przeprowadzonych $w$ ten sposób analiz stosując zasady analogiczne do wykorzystanych podczas analizy I. Pomimo tego, że podział zgrzewarek między skupienia uzyskany różnymi metodami nie jest identyczny, można wyróżnić charakterystyczne grupy zgrzewarek. Z punktu widzenia użytkownika najkorzystniejszymi właściwościami charakteryzują się zgrzewarki ze skupienia 2, a więc zgodnie z przyjętym założeniem z tej grupy wybrano urządzenie o najniższej cenie: C-23. Z rozważanej grupy również zgrzewarki C-25 i C-28 mają relatywnie niską cenę.

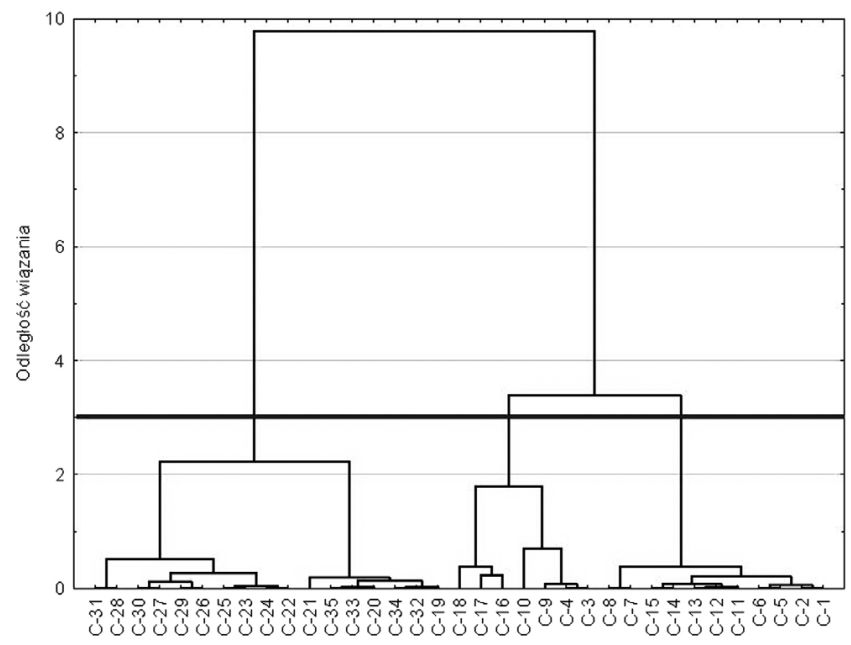

Rys. 4. Dendrogram klasyfikacji stacjonarnych zgrzewarek oporowych punktowych na podstawie cech: $P_{\text {nom }} N$, GN. Metoda Warda, odległość euklidesowa. Przerywaną linią zaznaczono poziom podziału na skupienia (analiza II)

Fig. 4. Euclidean distance dendrogram (Ward method) of stationary resistance spot-welding machines. Diagnostic factors: $P_{\text {nom }} N$, GN. The dashed line indicates the best option to divide the dendrogram into clusters (analysis II)

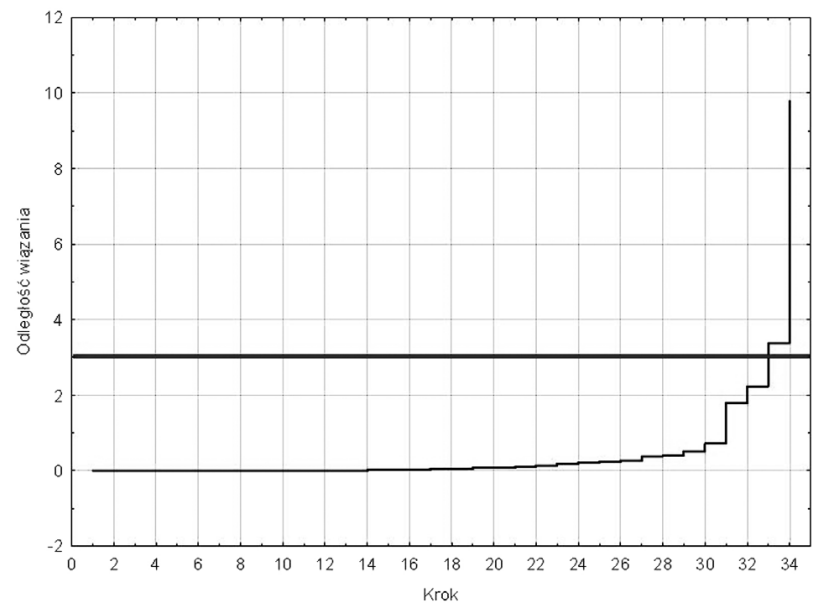

Rys. 5. Wykres odległości wiązania względem wiązania (analiza II) Fig. 5. Graph of the distance of the binding relative to the binding (analysis II)

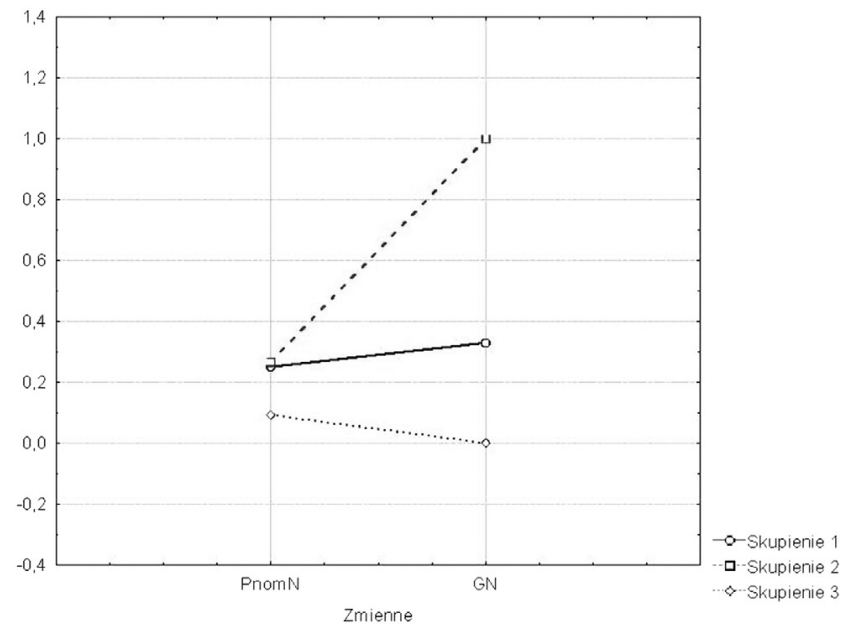

Rys. 6. Wykres liniowy średnich dla poszczególnych skupień stacjonarnych zgrzewarek oporowych punktowych na podstawie cech: $\mathrm{P}_{\text {nom }} \mathrm{N}, \mathrm{GN}$ (analiza II)

Fig. 6. K-means plot for clusters of stationary resistance spotwelding machines. Diag-nostic factors: $\mathrm{P}_{\text {nom N }}$ GN (analysis II)

Tablica IV. Wyniki grupowania stacjonarnych zgrzewarek oporowych punktowych na podstawie cech: $P_{\text {nom }} N, G N$ (analiza II) Table IV. Results of the grouping of stationary resistance spot-welding machines on the basis of the following factors: $\mathrm{P}_{\text {nom }} \mathrm{N}, \mathrm{GN}$ (analysis II)

\begin{tabular}{|c|c|c|c|}
\hline $\begin{array}{c}\text { Numer } \\
\text { skupienia }\end{array}$ & Elementy skupienia (metoda Warda) & Elementy skupienia (metoda k-średnich) & Opis skupienia \\
\hline 1 & C-3, C-4, C-9, C-10, C-16, C-17, C-18 & $\begin{array}{c}\text { C-16, C-17, C-18, C-19, C-20, C-21, C-32, } \\
\text { C-33, C-34, C-35 }\end{array}$ & $\begin{array}{c}\text { Przeciętna wartość } P_{\text {nom, }} \text { przeciętny } \\
\text { okres gwarancji }\end{array}$ \\
\hline 2 & $\begin{array}{c}\text { C-1, C-2, C-5, C-6, C-7, C-8, C-11, C-12, } \\
\text { C-13, C-14, C-15 }\end{array}$ & $\begin{array}{c}\text { C-1, C-2, C-3, C-4, C-5, C-6, C-7, C-8, C-9, } \\
\text { C-10, C-11, C-12, C-13, C-14, C-15 }\end{array}$ & $\begin{array}{c}\text { Najwyższa wartość } P_{\text {nom, }} \text { najdłuższy } \\
\text { okres gwarancji }\end{array}$ \\
\hline 3 & $\begin{array}{c}\text { C-19, C-20, C-21, C-22, C-23, C-24, C-25, } \\
\text { C-26, C-27, C-28, C-29, C-30, C-31, C-32, } \\
\text { C-33, C-34, C-35 }\end{array}$ & $\begin{array}{c}\mathrm{C}-22, \mathrm{C}-23, \mathrm{C}-24, \mathrm{C}-25, \mathrm{C}-26, \mathrm{C}-27, \mathrm{C}-28, \\
\text { C-29, C-30, C-31 }\end{array}$ & $\begin{array}{c}\text { Niska wartość } P_{\text {nom, }} \text { najkrótszy okres } \\
\text { gwarancji }\end{array}$ \\
\hline
\end{tabular}




\section{Podsumowanie i wnioski}

Zweryfikowano pozytywnie możliwość zastosowania metod analizy skupień do klasyfikacji i w dalszej kolejności do wspomagania decyzji zakupu stacjonarnych zgrzewarek oporowych punktowych. Podczas analizy rynku krajowego zgromadzono dane 35 urządzeń do zgrzewania, które uznano za próbę reprezentatywną dla rozważanej populacji statystycznej. Przeprowadzono badania taksonomiczne metodami Warda i k-średnich dwukrotnie: dla szerokiego zbioru cech (9 cech - analiza I) oraz dla minimalnej ilości cech diagnostycznych (2 cechy - analiza II).

Zaproponowano nowe $w$ odniesieniu do poprzednich prac $[12,13]$ podejście do problemu polegające na przyjęciu założenia, że z punktu widzenia nabywcy korzystne jest podejmowanie decyzji zakupu w dwóch etapach: najpierw wyodrębnienie grupy urządzeń o najkorzystniejszych cechach, a następnie wybranie z niej urządzenia o najniższej cenie.

W obu przypadkach uzyskano wyniki umożliwiające podjęcie obiektywnej decyzji zakupu. Wynikiem obu analiz był podział próby badanej na 3 grupy, które opisano poziomami cech diagnostycznych. W wyniku analizy I (9 cech diagnostycznych) jedynie 3 urządzenia zostały przypisane przez algorytmy Warda i k-średnich do innych skupień, natomiast zmniejszenie ilości cech do 2 spowodowało większe zróżnicowanie wyników.

Zastosowanie metod analizy skupień do klasyfikacji obiektów technicznych jest szczególnie uzasadnione w sytuacji porównywania dużej ilości obiektów wielocechowych. Przedstawione w artykule rozwiązanie nie wyczerpuje innych potencjalnych zastosowań. Zaproponowaną metodę można również wykorzystać do wyszukiwania zamienników, np. urządzeń o cechach zbliżonych do oczekiwanych.

O skuteczności metody decyduje głównie przyjęty zestaw cech diagnostycznych. Zmniejszenie ilości cech diagnostycznych wpływa na skrócenie czasu podjęcia decyzji i ułatwienie interpretacji wyników analiz poprzez skrócenie czasochłonnego etapu gromadzenia i przygotowania danych. Jednak może być przyczyną mniejszej dokładności wyników badań. Najistotniejszą wadą stosowania analiz statystycznych jest konieczność opanowania specjalistycznej wiedzy oraz obsługi oprogramowania. Należy także pamiętać o warunku przeprowadzenia analizy merytorycznej wyników badań statystycznych.

\section{Literatura}

[1] Chmielewski T.: Projektowanie procesów technologicznych - Spawalnictwo, Oficyna Wydawnicza Politechniki Warszawskiej, Warszawa 2013.

[2] Mikno Z., Bartnik Z.: Zgrzewanie rezystancyjne doczołowe zwarciowe w obliczeniach MES materiałów jednoimiennych. Cz. 1, Przegląd Spawalnictwa 87(4), 2015, s. 14-20.

[3] Chmielewski T., Jakubowski J.: Zgrzewanie rezystancyjne uszczelnień typu "plaster miodu", Prace Naukowe Politechniki Warszawskiej, Mechanika (229), 2009, s. 181-188.

[4] Vardanjani M., Senkara J., Arayee A.: A review of shunting effect in resistance spot welding, Przegląd Spawalnictwa 88(1), 2016, pp. 46-50.

[5] Hudycz M., Chmielewski T., Golański D.: Analysis of distribution of temperature and stresses during the friction metallisation of AIN ceramics with titanium. Biuletyn Instytutu Spawalnictwa w Gliwicach 60(5), 2016, pp. 63-67.

[6] Górka J.: Properties and structure of resistance short-circuit welded joints in TMCP steel S700MC, Biuletyn Instytutu Spawalnictwa w Gliwicach 62(1), 2018, pp. 37-41.

[7] Tuz L., Kołodziejczak P., Kolasa A.: Struktura złączy ze stopów magnezu wykonanych metodą FSW, Prace Naukowe Politechniki Warszawskiej, Mechanika (230) 2010, s. 135-146.

[8] Fydrych D., Rogalski G. Walczak W.: Wpływ cyklu cieplnego na właściwości zgrzewanych wybuchowo złączy stal-aluminium, Przegląd Spawalnictwa 85(6), 2013, s. 60-64.

[9] Pocica N., Tuz L.: Ocena mikrostruktury i wybranych własności mechanicznych złączy zgrzewanych wybuchowo po obróbce cieplnej, Przegląd Spawalnictwa 88(4), 2016, s. 35-38.

[10] Piwowarczyk T., Korzeniowski M., Ambroziak A., Kowal T., Rutka R., Karolewski M.: Effect of pipe face preparation on the quality of magnetically impelled arc welded joints, Biuletyn Instytutu Spawalnictwa w Gliwicach 60(5), 2016, pp. 111-119.

[11] Dobaj E.: Maszyny i urządzenia spawalnicze, WNT, Warszawa 1998.

[12] Fydrych D., Sommer S., Rogalski G.: Wspomaganie decyzji zakupu urządzeń do spawania metodą MIG/MAG z wykorzystaniem analizy skupień. Przegląd Spawalnictwa 86(12), 2014, s. 26-33.

[13] Fydrych D., Sommer S., Rogalski G.: Analiza skupień jako metoda wspomagania decyzji zakupu urządzeń prądu stałego do spawania metodą TIG, Logistyka 6, 2014, s. 14158-14164.

[14] Chmielewski T., Węglowski M.: Analiza rynku spawalniczego w Polsce pod względem sprzedaży urządzeń oraz materiałów spawalniczych, Przegląd Spawalnictwa 82(6), 2010, s. 28-31.

[15] Lasocki K.: Kryteria wyboru przy zakupie urządzeń i materiałów spawalniczych, Przegląd Spawalnictwa 70(12), 1998, s. 6-8.

[16] Stanisz A.: Przystępny kurs statystyki z zastosowaniem STATISTICA PL na przykładach medycyny, Tom 3, Analizy wielowymiarowe, Wydawnictwo StatSoft Polska, Kraków 2010.

[17] Czarnecka M., Nidzgorska-Lencewicz J.: Application of cluster analysis in defining the meteorological conditions shaping the variability of PM10 concentration, Rocznik Ochrona Środowiska 17(1), 2015, pp. 40-61.

[18] Filar B., Kwilosz T., Miziołek M., Piesik-Buś W., Zamojcin J.: The use of cluster analysis for the segmentation of the physicochemical properties of shale gas deposits, Nafta-Gaz 71(11), 2015, pp. 898-909.

[19] Wicijowski J., Ziółko B.: Analiza skupień i redukcja wymiarowości w hierarchicznym modelu korpusowym języka, Studia Informatica 31 (2A), 2010, s. $133-145$.

[20] Lee Y.F., Roe T., Mangham D.C., Fisher C., Grimer R.J., Judson I.: Gene expression profiling identifies distinct molecular subgroups of leiomyosarcoma with clinical relevance. British Journal of Cancer 115, 2016, pp. 1000-1007.

[21] Lin Q., Fan S., Zhang Y., Xu M., Zhang H., Yang Y., ..., Luo W.: The seahorse genome and the evolution of its specialized morphology, Nature 540(7633), 2016, pp. 395-399.

[22] Zhang H., Hou Y.: Quality estimation of the resistance spot welding based on genetic k-means cluster analysis. In Control, Automation and Systems Engineering (CASE), International Conference IEEE, 2011, pp. 1-4.

[23] Fydrych D., Rogalski G., Świerczyńska A., Łabanowski J.: Ocena przydatności komercyjnych elektrod otulonych do spawania mokrego pod wodą z wykorzystaniem analizy skupień, Przegląd Spawalnictwa 87(10), 2015, s. 27-30. 